\title{
Prediction of metabolic syndrome in women with polycystic ovary syndrome
}

\author{
Polikistik over sendromlu kadınlarda metabolik sendromun öngörüsü
}

\author{
Fırat Ersan ${ }^{1}$, Esra Arslan ${ }^{1}$, Aytül Çorbacıoğlu Esmer ${ }^{2}$, Serdar Aydın ${ }^{1}$, Asuman Gedikbaşı ${ }^{3}$, Ali Gedikbaşı ${ }^{1}$, \\ Issmet Alkış ${ }^{1}$, Cemal Ark ${ }^{1}$ \\ ${ }^{\prime}$ Clinic of Gynecology and Obstetrics, Kanuni Sultan Süleyman Research and Teaching Hospital, Istanbul, Turkey \\ ${ }^{2}$ Department of Gynecology and Obstetrics, Istanbul University Istanbul Faculty of Medicine, Istanbul, Turkey \\ ${ }^{3}$ Clinic of Biochemistry, Dr. Sadi Konuk Research and Teaching Hospital, Istanbul, Turkey
}

\section{Abstract}

Objective: To identify biochemical factors that serve as predictors for the metabolic syndrome (MetS) in patients with polycystic ovary syndrome (PCOS) and to investigate the value of adipocytokines in the prediction of metabolic syndrome.

Material and Methods: A total of 91 pre-menopausal women with PCOS diagnosed according to the Rotterdam consensus criteria were recruited as study subjects. Waist circumference, blood pressure, body mass index (BMI), fasting glucose, serum lipids, insulin, FSH, $\mathrm{LH}, \mathrm{E}_{2}$, total testosteron, homeostatic model assessment-insulin resistance (HOMA-IR), serum leptin and adiponectin levels were evaluated for all patients.

Results: Of the 91 women with PCOS, 15 patients met the criteria for MetS. Body weight, BMI, waist circumference, systolic blood pressure, diastolic blood pressure, fasting glucose, total cholesterol, triglyceride, and VLDL concentrations were significantly higher and HDL was significantly lower in women with PCOS+MetS compared with those with PCOS only. However, the level of LDL, FSH, LH, $\mathrm{E}_{2}$ and total testesterone was not significantly different between these two groups. Women with PCOS + MetS had significantly higher levels of leptin and HOMA-IR, and significantly lower levels of adiponectin compared to the women with PCOS only. In the multiple logistic regression model, the association between HOMA-IR and leptin, and MetS remained statistically significant $(p=0.001$ and 0.018$)$, while the association between adiponectin and MetS was no longer statistically significant.

Conclusion: Aside from the biochemical markers such as glucose, cholesterol and triglyceride, adipose tissue factors and insulin resistance are valuable parameters in the prediction of MetS in patients with PCOS. (J Turkish-German Gynecol Assoc 2012; 13: 178-83)

Key words: Metabolic syndrome, polycystic ovary syndrome, leptin, adiponectin, HOMA-IR

Received: 26 April, 2012

Accepted: 15 July, 2012
Özet

Amaç: Polikistik over sendromu (PKOS) tanısı almış hastalarda metabolik sendromun (MetS) öngörüsünde kullanılabilecek biyokimyasal faktörleri tanımlamak ve adipositokinlerin metabolik sendromun öngörüsündeki yerini araştırmak.

Gereç ve Yöntemler: Rotterdam kriterlerine göre PKOS tanısı almış olan 91 premenapozal kadın çalışma grubunu oluşturdu. Tüm hastaların bel çevresi, kan basıncı, vücut kitle indeksi (VKi), açlık kan şekeri, serum lipid düzeyleri, insülin, $\mathrm{FSH}, \mathrm{LH}, \mathrm{E}_{2}$, total testosteron, HOMA-IR (homeostatic model assessment-insulin direnci), serum leptin ve adiponektin seviyeleri değerlendirildi.

Bulgular: PKOS tanısı almış 91 kadından 15'i MetS kriterlerini taşıyordu. PKOS+MetS tanılı kadınlarda sadece PKOS tanılı kadınlara göre vücut ağırlığı, VKI, bel çevresi, sistolik kan basıncı, diastolik kan basıncı, açlık kan şekeri, total kolesterol, trigliserid ve VLDL düzeyleri anlamlı olarak yüksekken, HDL seviyesi anlamlı olarak düşük bulundu. Ancak, bu iki grup arasında LDL, FSH, LH, $\mathrm{E}_{2}$ ve total testesteron seviyeleri açısından istatistiksel olarak anlamlı bir fark yoktu. PKOS+MetS tanılı kadınlarda diğer kadınlara göre leptin ve HOMA-IR düzeyleri anlamlı olarak yüksek, adiponektin seviyesi ise anlamlı olarak düşüktü. Çoklu lojistik regresyon analizinde HOMA-IR ve leptin ile MetS arasındaki ilişki istatistiksel olarak anlamlı kalırken $(p=0.001$ ve 0.018$)$, adiponektin ile MetS arasındaki ilişki istatistiksel anlamını yitirdi.

Sonuç: Kan şekeri, kolesterol ve trigliserid gibi biyokimyasal belirteçlerin dışında, yağ dokusu faktörleri ve insülin direnci de PKOS hastalarında MetS öngörüsü açısından değerlidir.

(J Turkish-German Gynecol Assoc 2012; 13: 178-83)

Anahtar kelimeler: Metabolik sendrom, polikistik over sendromu, leptin, adiponektin, HOMA-IR

Geliş Tarihi: 26 Nisan 2012

Kabul Tarihi: 15 Temmuz 2012

\section{Introduction}

Polycystic ovary syndrome (PCOS) is a frequent endocrine disorder affecting 6-12\% of reproductive-age women (1). Oligo-amenorrhea, chronic anovulation, hyperandrogenism, hirsutism, and infertility are some of the well-defined clini- cal manifestations of PCOS. It is also considered as a metabolic disorder, since the components of metabolic syndrome (MetS), namely obesity, glucose intolerance, atherogenic dyslipidemia, and hypertension, are the common features of this syndrome. Although MetS and PCOS have overlapping features, and both cause an increased risk of cardiovascular 
disease, the pathophysiology that may link these two remains unclear. Possible theories regarding the association between MetS and PCOS include: (1) insulin resistance underlies the pathogenesis of both MetS and PCOS, (2) obesity and related adipose tissue factors (adipocytokins) independent of insulin resistance are the major pathogenic contributors to both conditions.

With the identification of adipose tissue as the source of leptin in 1994, adipose tissue transformed from a passive organ storing energy to an active endocrine organ which produces a variety of locally and systematically functioning bioactive molecules. The adipocyte-derived $16 \mathrm{kDa}$ hormone leptin is a critical mediator of energy balance that relays information regarding the depletion or accumulation of fat stores to the brain. Effects on immune system, reproduction, angiogenesis and blood pressure are some of the widely varying peripheral and central actions of leptin (2). Both the granulosa and theca cells of the human ovarian follicule have leptin receptors and it has been shown that granulosa cells can secrete leptin, which indicates a direct paracrine role for leptin at the ovarian follicular level (3). Moreover, elevated leptin level is a common feature in obese subjects, and it has been suggested that it could represent an additional factor involved in the development of insulin resistance and in the impairment of ovarian function, particularly in women with PCOS (4).

Another molecule secreted by adipose tissue, adiponectin, is a 224-amino acid adipose specific protein, which was first identified in 1995. It has a molecular weight of $30 \mathrm{kDa}$, and is also referred to as Adipocyte Complement-Related Protein $30 \mathrm{kDa}$ (ACRP30). Adiponectin supresses almost all processes involved in atherosclerotic vascular changes including the expression of adhesion molecules in vascular endothelial cells, the proliferation of vascular smooth muscle cells and the formation of foam cells in vitro, and it exhibits an anti-atherosclerotic activity in vivo (5). Adiponectin is the only known protein that is produced in adipose tissue and it decreases in obesity (6). It is demonstrated that adiponectin has insulin-sensitizing activity, and the high level of plasma adiponectin is a negative risk factor for type 2 diabetes in diabetes-prone people (7). It has been shown to be correlated negatively with triglyceride level, fasting plasma glucose level, plasma glucose level two hours after a meal and fasting insulin concentration, and correlated positively with the high-density lipoprotein level $(7,8)$. Recent studies have also shown that adiponectin is related to endothelium-dependent vasodilatation and its plasma concentrations are low in subjects with essential hypertension (9).

In the present study, we aimed to find the predictive value of adiponectin and leptin in the assessment of MetS and to evaluate their relationship with severity of insulin resistance and hyperandrogenemia in patients with PCOS. We also aimed to find biochemical predictors of MetS in women with PCOS.

\section{Material and Methods}

\section{Subjects, definitions and study design}

This was a cross-sectional study conducted in the Gynecology Department of Kanuni Sultan Suleyman Research and Teaching
Hospital between April 2008 and June 2010. A total of 91 Turkish pre-menopausal women with PCOS were recruited as study subjects. The diagnosis of PCOS was based on the Rotterdam PCOS consensus (Rott-PCOS) criteria (10). According to these criteria, PCOS was diagnosed if at least two of the following criteria were present: oligo/amenorrhea, clinical or biochemical hyperandrogenism and PCO on ultrasonography. Clinical hyperandrogenism was defined as the presence of hirsutism (Ferriman-Galwey score >8) and/or acne. Biochemical hyperandrogenism was defined as elevated total testesterone. PCO was defined as the presence of at least one ovary with 12 or more follicles measuring 2-9 mm in diameter (11). Other etiologies that could mimic PCOS, such as Cushing syndrome, thyroid dysfunction, hyperprolactinemia, adrenal hyperplasia or andogen producing neoplasm were excluded. The use of medications known or suspected to affect reproductive or metabolic function was prohibited within 60 days prior to study entry. This study was approved by the institutional review boards ofour center and all subjects provided written informed consent.

MetS was defined according to NCEP ATP III guidelines (12). MetS was diagnosed if at least three of the following five features were present: (i) central obesity with waist circumference $>88 \mathrm{~cm}$, (ii) elevated serum triglyceride $>150 \mathrm{mg} / \mathrm{dL}$, (iii) reduced serum high-density lipoprotein (HDL)-cholesterol $<50$ $\mathrm{mg} / \mathrm{dL}$ or the use of lipid lowering medication, (iv) elevated systolic and/or diastolic blood pressure $>130 / 85 \mathrm{mmHg}$ or the use of antihypertensive medication, (v) impaired fasting glucose $>100 \mathrm{mg} / \mathrm{dL}$.

Insulin resistance (IR) was assessed using the homeostatic model assessment (HOMA-IR: fasting insulin $(\mu \mathrm{U} / \mathrm{mL}) \mathrm{x}$ fasting glucose (mg/dL)/405) (13).

\section{Physical examination, ultrasound and laboratory analyses}

A standard questionnaire was used to document personal, medical, and drug history, regularity and length of menstrual cycles, ovulation status, symptoms of hirsutism and acne. Signs of androgen excess were noted during the physical examination. Body weight $(\mathrm{kg})$, body height $(\mathrm{m})$, and waist circumference (WC) $(\mathrm{cm})$ were measured. Waist circumference was taken as the narrowest measurement between the top of the iliac crest and the lower rib margin. Sitting systolic and diastolic blood pressures (SBP-DBP) were measured after a 5-min rest using a standard sphygmomanometer. Hirsutism was established by using the Ferriman-Gallwey score. Transvaginal ultrasonography was systematically performed by the same investigator (E.A.) on a Logiq 9, using the $4 \mathrm{MHz}$ transvaginal probe. Overnight fasting blood specimens were obtained in all women for measurement of fasting plasma glucose (FPG), total cholesterol (TC), triglycerides (TG), low-density lipoprotein cholesterol (LDL-C), very low-density lipoprotein cholesterol (VLDL-C), high-density lipoprotein cholesterol (HDL-C), adiponectin, and leptin. Serum $\mathrm{LH}, \mathrm{FSH}$, and total testosterone concentrations were measured on the third day of either spontaneous or progesterone-induced menstruation.

After clot formation, blood samples were centrifuged at $4^{\circ} \mathrm{C}$ for 15 minutes at $2000 \times \mathrm{g}$. Serum fasting blood glucose, lipid levels, thyroid function tests, fertility hormones and insulin levels were 
determined on the same day. Aliquots of serum samples were stored at $-80^{\circ} \mathrm{C}$ until leptin and adiponectin assaying. Glucose, total cholesterol, triglycerides, HDL and LDL cholesterol, free T4, free T3, TSH, FSH, LH, estradiol, progesterone, prolactin, and testosterone levels were analyzed with Architect c16200 Integrated System (Abbott Diagnostics Europe, Wiesbaden, Germany). Serum insulin levels were determined by Siemens Immulite 1000 immunoassay system (Siemens Healthcare Diagnostics, USA) Serum adiponectin levels were determined using AssayMax Human adiponectin ELISA Kit (Acrp30) (catalog EA2500-1, Lot 7250521), purchased from Assay Pro (USA) following the manufacturer's instructions. AssayMax Human adiponectin ELISA Kit employs the quantitative sandwich enzyme immunoassay technique. Intra-assay and inter-assay coefficients of variation were $4.2 \%$ and $7.3 \%$ respectively. Adiponectin levels were expressed as $\mu \mathrm{g} / \mathrm{ml}$. Serum Leptin levels were measured using DRG Leptin (Sandwich) ELISA kit (EIA-2395) purchased from DRG Instruments (GmbH, Germany) following the manufacturer's recommendations. Intra-assay and interassay coefficients of variation were $5.9 \%$ and $8.6 \%$ respectively.

\section{Statistical analysis}

In this study, the data were analyzed using NCSS 2007. Continuous variables were presented as mean \pm SD and ana- lysed using independent sample t-test. Categorical variables were presented as $\mathrm{X}^{2}$ test. Cut off for HOMA-IR, leptin and adiponectin variables was determined and areas under ROC curves were calculated and compared. For determining factors that were effective in the differential diagnosis of metabolic syndrome, logistic regression analysis was performed. Statistical significance was considered present if the P-value was $<0.05$, 95\% CI.

\section{Results}

Table 1 shows the comparison of clinical and biochemical characteristics of women with PCOS only and women with PCOS + MetS. Of the 91 women, 15 patients met the criteria for MetS. Women in these two groups were similar in age and height. As expected, compared with the women who did not meet criteria for the MetS, those with the MetS had a significantly higher body weight, BMI, waist circumference, systolic blood pressure, and diastolic blood pressure. In addition, fasting glucose, total cholesterol, triglyceride, and VLDL concentrations were significantly higher in those with PCOS+MetS. Also, HDL was significantly lower in the PCOS+MetS group. However, the difference in LDL was not significant between these two groups, nor were the levels of $\mathrm{FSH}, \mathrm{LH}, \mathrm{E}_{2}$ and total testesterone.

Table 1. Comparison of clinical and biochemical characteristics of women with PCOS only and women with PCOS + MetS

\begin{tabular}{|c|c|c|c|}
\hline & PCOS only (n:76) & PCOS+MetS (n:15) & $\mathbf{P}$ \\
\hline Age (year) & $24.11 \pm 4.73$ & $25.93 \pm 4.95$ & NS \\
\hline Height (m) & $1.6 \pm 0.06$ & $1.58 \pm 0.07$ & NS \\
\hline Weight (kg) & $63.72 \pm 12.84$ & $78.87 \pm 11.15$ & 0.0001 \\
\hline BMI $\left(\mathrm{kg} / \mathrm{m}^{2}\right)$ & $24.8 \pm 5.01$ & $31.47 \pm 4.1$ & 0.0001 \\
\hline $\mathrm{WC}(\mathrm{cm})$ & $82.46 \pm 9.45$ & $94.6 \pm 6.89$ & 0.0001 \\
\hline SBP (mmHg) & $110.13 \pm 14.28$ & $124.67 \pm 13.02$ & 0.0001 \\
\hline $\mathrm{DBP}(\mathrm{mmHg})$ & $68.42 \pm 8.8$ & $76.67 \pm 10.47$ & 0.002 \\
\hline Glucose (mg/dL) & $87.5 \pm 13.57$ & $109.33 \pm 15.37$ & 0.0001 \\
\hline Total cholesterol (mg/dL) & $160.86 \pm 39.63$ & $186.53 \pm 24.97$ & 0.018 \\
\hline HDL-C (mg/dL) & $42.33 \pm 9.2$ & $37.27 \pm 7.69$ & 0.049 \\
\hline Triglyceride (mg/dL) & $94.51 \pm 49.01$ & $151.07 \pm 52.64$ & 0.0001 \\
\hline VLDL-C (mg/dL) & $18.9 \pm 9.8$ & $30.21 \pm 10.53$ & 0.0001 \\
\hline LDL-C (mg/dL) & $99.7 \pm 36.86$ & $119.09 \pm 20.37$ & NS \\
\hline FSH (mIU/mL) & $5.18 \pm 1.71$ & $4.78 \pm 1.96$ & NS \\
\hline $\mathrm{LH}(\mathrm{mIU} / \mathrm{mL})$ & $8.46 \pm 4.65$ & $6.64 \pm 4.9$ & NS \\
\hline $\mathrm{E}_{2}(\mathrm{pg} / \mathrm{mL})$ & $70.34 \pm 62.66$ & $51.8 \pm 35.41$ & NS \\
\hline Total testosterone $(\mathrm{pg} / \mathrm{mL})$ & $0.87 \pm 0.35$ & $0.71 \pm 0.33$ & NS \\
\hline HOMA- IR & $1.95 \pm 1.72$ & $8.81 \pm 7.59$ & 0.0001 \\
\hline Leptin (ng/mL) & $30.35 \pm 11.6$ & $44.37 \pm 14.34$ & 0.0001 \\
\hline Adiponectin $(\mu \mathrm{g} / \mathrm{mL})$ & $9.76 \pm 4.57$ & $6.15 \pm 3.54$ & 0.005 \\
\hline
\end{tabular}


Moreover, the women with PCOS + MetS had significantly higher levels of leptin and HOMA-IR (both $\mathrm{p}=0.0001$ ), and significantly lower levels of adiponectin compared with the women with PCOS only $(\mathrm{p}=0.005)$.

We constructed receiver operating characteristic (ROC) curves (Figure 1) and calculated the area under the curve (AUC) value as 0.833 for HOMA-IR, 0.805 for leptin, and 0.819 for adiponectin. Then we made pairwaise comparison of ROC curves and we found statistically no difference between the AUC values of these parameters. For predicting metabolic syndrome, cut-off points for HOMA-IR, leptin and adiponectin were determined. When HOMA-IR was $\geq 2.51$ sensitivity, specificity, positive predictive value, negative predictive value and likelihood ratio were $86.67 \%, 73.68 \%, 39.4 \%, 96.6 \%$, and $3.29 \%$, respectively. When leptin level was $\geq 35.7$ the corresponding statistics were $73.33 \%, 77.63 \%, 39.30 \%, 93.70 \%$ and $3.28 \%$, and when adiponectin level was $\leq 6,45$ they were $80 \%, 76.32 \%, 40 \%, 95.1 \%$ and $3.38 \%$, respectively (Table 2 ).

In the multiple logistic regression model, the association between HOMA-IR and leptin, and MetS remained statistically significant $(\mathrm{p}=0.001$ and 0.018$)$, while the association between adiponectin and MetS was no longer statistically significant (Table 3).

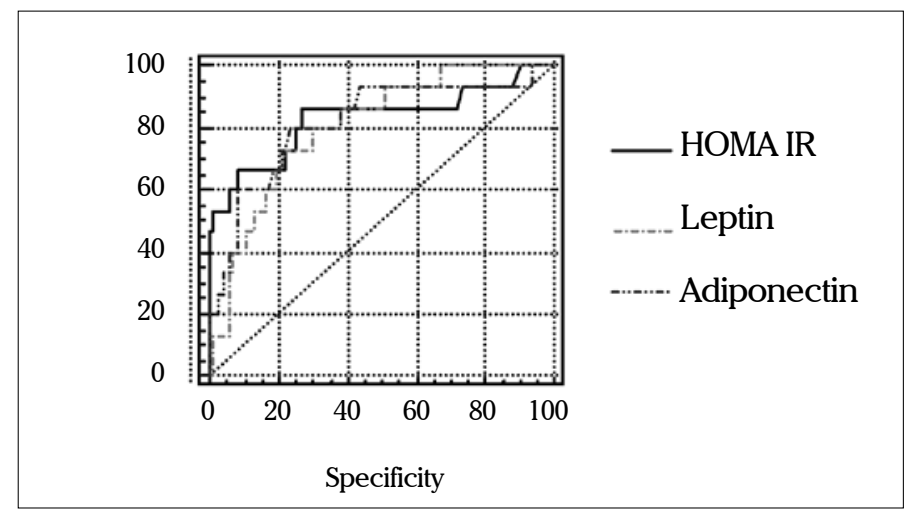

Figure 1. ROC curves for selected variables and the presence of metabolic syndrome

\section{Discussion}

The prevalence of MetS has been shown to range between $8.2 \%$ and $14.3 \%$ according to the criteria used in women with PCOS, as opposed to $2.7 \%$ and $6.6 \%$ in the control group (14). The most likely pathogenic link between PCOS and MetS is insulin resistance and compensatory hyperinsulinism. In one study, the prevalence of insulin resistance was reported to be $32 \%$ among women with PCOS (15). Although hyperinsulinemic euglycemic clamp technique is the gold standard for measuring insulin sensitivity, it is expensive, time consuming, and invasive (16). The homeostatic model assessment of IR (HOMA-IR) is a simple and noninvasive method for estimating insulin sensitivity from the steady glucose and insulin concentrations measured under fasting conditions. It generally correlates well with clamp techniques. In this study we used HOMA-IR as a surrogate marker of insulin resistance, and we postulated that women with concomitant PCOS and MetS would have more insulin resistance than women with PCOS only. We found HOMA-IR values of these two groups $8.81 \pm 7.59$ and $1.95 \pm 1.72$, respectively $(p=0.0001)$. This finding is in agreement with other studies who have found that all surrogate markers of reduced insulin sensitivity are more obvious in women with concomitant PCOS and MetS than women without MetS (17-19).

Hyperandrogenism has been shown to be a risk factor for insulin resistance in PCOS cases (15). However, in our study women with PCOS only and women with PCOS+MetS did not show any significant difference in terms of total testesterone. While this finding is consistent with some studies in the literature $(18,19)$, it is in contrast with others $(20)$. It has been also shown that hyperinsulinemia and lipid abnormalities remained unchanged despite the use of $\mathrm{GnRH}$ to suppress androgens in hirsute hyperandrogenic women (21). As a consequence of these findings, it can be suggested that hyperandrogenism by itself may not contribute to the development of MetS in women with PCOS.

Table 2. Diagnostic performance of HOMA-IR, leptin and adiponectin in the differentiation of metabolic syndrome

\begin{tabular}{|l|c|c|c|c|c|c|c|}
\hline & Cut Off & Sensitivity & Specificity & PPV & NPV & +LR & -LR \\
\hline HOMA IR & $>2.51$ & 86.67 & 73.68 & 39.4 & 96.6 & 3.29 & 0.18 \\
\hline Leptin & $>35.7$ & 73.33 & 77.63 & 39.3 & 93.7 & 3.28 & 0.34 \\
\hline Adiponectin & $<6.45$ & 80.00 & 76.32 & 40.0 & 95.1 & 3.38 & 0.26 \\
\hline \multicolumn{2}{l}{ PPV: Positive predictive value, NPV: Negative predictive value, LR: Likelihood ratio } \\
\hline
\end{tabular}

Table 3. Multivariate logistic regression analysis

\begin{tabular}{|l|c|c|c|c|c|c|}
\hline & B & S.E. & p & \multicolumn{3}{|c|}{ 95.0\% C.I.for EXP(B) } \\
\cline { 3 - 7 } & & & & Exp (B) & Lower & Upper \\
\hline HOMA-IR & 0.657 & 0.17 & 0.001 & 1.77 & 1.26 & 1.01 \\
\hline Leptin & 0.069 & 0.07 & 0.018 & 1.07 & 0.78 & 1.13 \\
\hline Adiponectin & -0.32 & 0.18 & 0.076 & & & 1.03 \\
\hline Constant & -3.77 & 2.62 & 0.004 & & \\
\hline
\end{tabular}


Although current theories focus on insulin resistance as the prime factor linking visceral obesity with adverse metabolic changes, studies suggest that the pathophysiology of MetS cannot be explained by insulin resistance alone. Beyond glucose homeostasis; dyslipidemia, blood pressure, and many other pathophysiologic features have been characterized in individuals with MetS. Also, adipose tissue factors (adipocytokins) play an important role in the pathogenesis of this syndrome. Previous studies showed that adiponectin was closely associated with visceral fat accumulation and insulin resistance, and the low levels of adiponectin were linked to the components of MetS $(7,8,22)$. It has been also reported that adiponectin level might be useful for the diagnosis of MetS in obese Japanese children (23). According to the effects of excess adiposity and IR on adiponectin levels, a marked decrease of adiponectin levels in women with PCOS can be assumed. This assumption has been confirmed by the findings of numerous studies $(24,25)$. As mentioned above, both MetS and PCOS are related with low adiponectin levels and it is expected that women with concomitant PCOS and MetS would have lower adiponectin levels compared to women with PCOS only. In this study, similar to previous studies, adiponectin levels were detected lower in PCOS patients with MetS.

Clearly, serum leptin concentrations rise in proportion to the body adiposity. Therefore, obese individuals with MetS generally have higher circulating leptin concentrations. However, obese individuals seem to be resistant to the hypothalamic effects of leptin, and the catabolic pathways designed to reduce appetite and increase energy expenditure are not activated, therefore, excess body weight is maintained. In animal models of pharmacologically induced PCOS (rats with dihydrotestosterone-induced PCOS) real-time reverse-transcriptase PCR detected that the level of leptin expression in visceral fat of rats with PCOS was higher than that of controls (26). Several reports show that women with PCOS have higher circulating concentrations of leptin as compared with controls $(27,28)$. The role of hyperleptinemia in women with PCOS is not clear yet, but there is a possibility that women with PCOS are leptin resistant. In this study leptin levels were significantly elevated in women with concomitant MetS and PCOS. It is probably the result of the concomitant presence of two leptin resistant conditions, PCOS and MetS, in the same group of patients.

Screening all women with PCOS for the presence of MetS is expensive. For this reason, screening should be limited to only those women particularly at risk for MetS. At the Rotterdam consensus meeting, it was mentioned that obese PCOS patients should be screened for MetS, but they did not give specific criteria or validity for screening these women. In the literature, there are a few studies that were performed to find the methods of the prediction of MetS in patients with PCOS. Goverde et al. (29) found that a combination of waist circumference and free androgen index (FAI) offers the best selection criterion for the presence of either MetS or IR. Another study suggested use of the triglyceride/HDL-cholesterol ratio (TG/HDL-C ratio) $>3.2$ as a criterion to screen for MetS in hyperandrogenic women (AUC 0.941, sensitivity 90.9\%, specificity 87.5\%) (19). In this study, HOMA-IR, adiponectin and leptin were found to be suitable for the differential diagnosis of MetS and cut off points were defined in a cohort of women diagnosed with PCOS. However, this study was not without limitations. HOMA-IR may have underestimated the true prevalence of IR. Even though the gold standard for the diagnosis of IR is euglycemic hyperinsulinemic clamp, we opted to use HOMA-IR, because euglycemic hyperinsulinemic clamp technique is too expensive and complicated to use in clinical practice and large-scale studies.

\section{Conclusion}

In the management of PCOS it is essential to differentiate the women particularly at risk for MetS. To our knowledge this is the first study that investigate the value of adipocytokines in the prediction of MetS in patients with PCOS. We have found that adiponectin, leptin and HOMA-IR levels are significantly different between women with PCOS only and women with PCOS + MetS, as well as the other biochemical markers, such as glucose, cholesterol and triglycerides. However, these markers are very expensive and impractical for clinical use. Therefore, more studies are required in order to find the optimum biochemical or clinical markers that predict the presence of MetS in patients with $\mathrm{PCOS}$.

\section{Conflict of interest}

No conflict of interest was declared by the authors.

\section{References}

1. Azziz R, Woods KS, Reyna R, Key TJ, Knochenhauer ES, Yildiz BO. The prevalence and features of the polycystic ovary syndrome in an unselected population. J Clin Endocrinol Metab 2004; 89: 2745-9. [CrossRef]

2. Fruhbeck G. A heliocentric view of leptin. Proc Nutr Soc 2001; 60: 301-18. [CrossRef]

3. Pirwany IR, Fleming R, Sattar N, Greer IA, Wallace AM. Circulating leptin concentrations and ovarian function in polycystic ovary syndrome. Eur J Endocrinol 2001; 145: 289-94. [CrossRef]

4. Pasquali R, Gambineri A, Pagotto U. The impact of obesity on reproduction in women with polycystic ovary syndrome. BJOG 2006; 113: 1148-59. [CrossRef]

5. Okamoto Y, Arita Y, Nishida M, Muraguchi M, Ouchi N, Takahashi M, et al. An adipocyte-derived plasma protein, adiponectin, adheres to injured vascular walls. Horm Metab Res 2000; 32: 47-50. [CrossRef]

6. Arita Y, Kihara S, Ouchi N, Takahashi M, Maeda K, Miyagawa J, et al. Paradoxical decrease of an adipose-specific protein, adiponectin in obesity. Biochem Biophys Res Commun 1999; 257: 79-83. [CrossRef]

7. Lindsay RS, Funahashi T, Hanson RL, Matsuzawa Y, Tanaka S, Tataranni PA, et al. Adiponectin and development of type 2 diabetes in the Pima Indian population. Lancet 2002; 360: 57-8. [CrossRef]

8. Matsubara M, Maruoka S, Katayose S. Decreased plasma adiponectin concentrations in women with dyslipidemia. J Clin Endocrinol Metab 2002; 87: 2764-9. [CrossRef]

9. Ouchi N, Ohishi M, Kihara S, Funahashi T, Nakamura T, Nagaretani $\mathrm{H}$, et al. Association of hypoadiponectinemia with impaired vasoreactivity. Hypertension 2003; 42: 231-4. [CrossRef]

10. Rotterdam ESHRE/ASRM-Sponsored Consensus Workshop Group. Revised 2003 consensus on diagnostic criteria and long-term health risks related to polycystic ovary syndrome. Fertil Steril 2004; 81: 19-25. [CrossRef] 
11. Balen AH, Laven JS, Tan SL, Dewailly D. Ultrasound assessment of the polycystic ovary: international consensus definitions. Hum Reprod Update 2003; 9: 505-14. [CrossRef]

12. Expert Panel on the Diagnosis, Evaluation, and Treatment of High Blood Cholesterol in Adults. Executive Summary of The Third Report of The National Cholesterol Education Program (NCEP) Expert Panel on Detection, Evaluation, And Treatment of High Blood Cholesterol in Adults (Adult Treatment Panel III). JAMA 2001; 285: 2486-97. [CrossRef]

13. Legro RS, Castracane VD, Kauffman RP. Detecting insulin resistance in polycystic ovary syndrome: purposes and pitfalls. Obstet Gynecol Surv 2004; 59: 141-54. [CrossRef]

14. Çalışkan E, Kılıç T, Bodur H, Zeteroğlu Ş. The frequency of metabolic syndrome in women with polycystic ovaries at reproductive age and comparison of different diagnostic criteria for metabolic syndrome. J Turkish German Gynecol Assoc, 2007; 8: 402-7.

15. Sharaf H, Saygilı H, Kartal A. Relation between insulin resistance and the clinical and laboratory findings in polycystic ovary syndrome patients. J Turkish German Gynecol Assoc 2004; 5: 303-9.

16. DeFronzo RA, Tobin JD, Andres R. Glucose clamp technique: a method for quantifying insulin secretion and resistance. Am J Physiol 1979; 237: E214-23.

17. Ehrmann DA, Liljenquist DR, Kasza K, Azziz R, Legro RS, Ghazzi MN. Prevalence and predictors of the metabolic syndrome in women with polycystic ovary syndrome. J Clin Endocrinol Metab 2006; 91: 48-53. [CrossRef]

18. Cheung LP, Ma RC, Lam PM, Lok IH, Haines CJ, So WY, et al. Cardiovascular risks and metabolic syndrome in Hong Kong Chinese women with polycystic ovary syndrome. Hum Reprod 2008; 23: 1431-8. [CrossRef]

19. Dokras A, Bochner M, Hollinrake E, Markham S, Vanvoorhis B, Jagasia DH. Screening women with polycystic ovary syndrome for metabolic syndrome. Obstet Gynecol 2005; 106: 131-7. [CrossRef]

20. Apridonidze T, Essah PA, Iuorno MJ, Nestler JE. Prevalence and characteristics of the metabolic syndrome in women with polycystic ovary syndrom. J Clin Endocrinol Metab 2005; 90: 1929-35. [CrossRef]
21. Wild RA, Alaupovic P, Parker IJ. Lipid and apolipoprotein abnormalities in hirsute women. I. The association with insulin resistance. Am J Obstet Gynecol 1992; 166: 1191-7.

22. Mohan V, Deepa R, Pradeepa R, Vimaleswaran KS, Mohan A, Velmurugan $\mathrm{K}$, et al. Association of low adiponectin levels with the metabolic syndrome-the Chennai Urban Rural Epidemiology Study (CURES-4). Metabolism 2005; 54: 476-81. [CrossRef]

23. Ogawa Y, Kikuchi T, Manasaki K, Hiura M, Tanaka Y, Uchiyama M. Usefulness of serum adiponectin level as a diagnostic marker of metabolic syndrome in obese Japanese children. Hypertens Res 2005; 28: 51-7. [CrossRef]

24. Ardawi MS, Rouzi AA. Plasma adiponectin and insulin resistance in women with polycystic ovary syndrome. Fertil Steril 2005; 83: 1708-16. [CrossRef]

25. Aroda V, Ciaraldi TP, Chang SA, Dahan MH, Chang RJ, Henry RR. Circulating and cellular adiponectin in polycystic ovary syndrome: relationship to glucose tolerance and insulin action. Fertil Steril 2008; 89: 1200-8. [CrossRef]

26. Mannerås L, Jonsdottir $\mathrm{IH}$, Holmäng A, Lönn M, Stener-Victorin E. Low-frequency electro-acupuncture and physical exercise improve metabolic disturbances and modulate gene expression in adipose tissue in rats with dihydrotestosterotie-induccd polycystic ovary syndrome. Endocrinology 2008; 149: 3559-68. [CrossRef]

27. Li MG, Ding GL, Chen XJ, Lu XP, Dong LJ, Dong MY, et al. Association of serum and follicular liquid leptin concentrations with granulosa cell phosphorylated signal transducer and activator of transcription 3 expression in fertile patients with polycystic ovarian syndrome. $\mathrm{J}$ Clin Endocrinol Metab 2007; 92: 4771-6. [CrossRef]

28. Mancini F, Cianciosi A, Reggiani GM, Facchinetti F, Battaglia C, de Aloysio D. Endothelial function and its relationship to leptin, homocysteine, and insulin resistance in lean and overweight eumenorrheic women and PCOS patients: a pilot study. Fertil Steril 2009; 91: 2537-44. [CrossRef]

29. Goverde AJ, van Koert AJ, Eijkemans MJ, Knauff EA, Westerveld HE, Fauser BC, et al. Indicators for metabolic disturbances in anovulatory women with polycystic ovary syndrome diagnosed according to the Rotterdam consensus criteria. Hum Reprod 2009; 24: 710-7. [CrossRef] 